\title{
Milk NAGase Activity as an Indicator of Subclinical and Clinical Mastitis in Sahiwal Cows
}

\author{
R. Selva Rani*, Sujata Pandita and Manju Ashutosh
}

National Dairy Research Institute (NDRI), Karnal, Haryana-132001, India

*Corresponding author

\section{A B S T R A C T}

\section{Keywords}

Milk, Subclinical /clinical mastitis, CMT, NAGase activity, Sahiwal

\section{Article Info}

Accepted:

20 May 2020

Available Online:

10 June 2020
Present investigation was undertaken to evaluate the milk NAGase activity of Sahiwal cows suffering with subclinical or clinical mastitis. The incidence of occurrence of subclinical and clinical mastitis was evaluated by testing fresh milk samples by California Mastitis Test (CMT). A total of 73 Sahiwal cows in early lactation selected from the NDRI herd during different seasons. From this 12 clinical and 12 subclinical cases distributed over three different seasons were taken into account. Clinical mastitis cases had significantly higher $(\mathrm{P}<0.05)$ milk NAGase levels as compared to subclinical mastitis cases. Thus, it was found to be the most potential candidates in milk which could be used for detecting subclinical mastitis.

\section{Introduction}

Mastitis is an inflammation of mammary gland which result in reduction of milk yield and quality, high incidence of culling rate , mortality and the potential to serve as health risk to other cows in the farm (Boehmer et al., 2008; Viguier et al., 2009). Bovine mastitis causes significant economic problem in the dairy farm as well as the dairy industry (Vicente, 2014). Dairy cows are exposed to numerous physiological, environmental and genetic factors which compromise the host immune system and increase the incidence of mastitis (Sordillo, 2005). NAGase is an intracellular lysosomal enzyme that is released into milk from neutrophils during phagocytosis and cell lysis but also from damaged epithelial cells, indicating udder tissue destruction (Kitchen, 1981). Milk NAGase activity correlated very closely with SCC (Kitchen, 1981; Mattila et al., 1986). NAGase activity accurately reflects the degree of inflammation, so that in mastitis caused by major pathogens milk NAGase activity is significantly higher than in mastitis caused by minor pathogens (Kitchen et al., 1984; Mattila et al., 1986; Pyorala and Syvajarvi, 1987, Miller and Paape, 1988). Kitchen et al., (1984) applied NAGase assay 
to estimate the somatic cell counts as a marker for mastitic milk. Mellor (1968) reported firstly the presence of NAGase in bovine milk and suggested that bovine milk NAGase is derived wholly from the leukocytes and their level in milk was helpful for detection of udder health. Ulberth et al., (1984) reported that sensitivity and specificity of the NAGase assay did not differ from cell count determination. Differences in the lysosomal enzyme activities between the classes of animal leukocytes were reported by Healy, (1984). In cattle higher NAGase activity was found in granulocytes. Kitchen et al., (1978) reported that mammary gland secretory cells contained high levels of NAGase and appeared to be the major source of enzyme in milk whereas NAGase was from other sources (white blood cells and blood serum) contributed only $5-15 \%$ of the total activity in milk. A higher NAGase activity was found in serum, macrophage and neutrophils. From these results, it could be derived that most of NAGase activity in milk was from blood serum, macrophage and neutrophils and were associated with the inflammatory process. In normal quarter NAGase activity were $9.5 \mathrm{nM} / \mathrm{min} / \mathrm{ml}$ but in acute clinical mastitis it increased remarkably from 25 to $500 \mathrm{nM} / \mathrm{min} / \mathrm{ml}$. In chronic mastitis this changes were small.

Aim of this study was to evaluate milk NAGase as a potential candidate to detect subclinical mastitis in Sahiwal cows

\section{Materials and Methods}

The animals were selected from the herd maintained at Livestock Research Centre (LRC) of NDRI, Karnal, Haryana. The animals were kept under normal routine management practice as followed at the institute's farm. All the cows were fed as per the standard feeding practices which consisted of concentrate mixture (mustard cake, maize, wheat bran, rice bran, mineral mixture and common salt) wheat straw and roughages (berseem, maize or jowar fodder). The feed and water was available adlibidum to these cows.

A total of 73 Sahiwal in early lactation selected from the NDRI herd during different seasons were included in this study. The incidence of occurrence of subclinical and clinical mastitis was evaluated by testing fresh milk samples by California Mastitis Test (CMT). which included 12 clinical and 12 subclinical cases distributed over three different seasons [4 cows of each breed with clinical and subclinical infection in each season i.e. thermo neutral (OctoberNovember), winter (December to January) and summer (April 15 ${ }^{\text {th }}$-May)]. THI during the experimental period has been shown in the figure 1 .

NAGase activity was evaluated both in milk and plasma using ELISA kit which was purchased from Bioassay Technology Laboratory. The samples of composite milk (representing all four quarters) were collected in tube $(250 \mathrm{ml})$ from SCM and CM affected cows during noon milking (12.00 Noon). Immediately after collection, the tubes were transported to the laboratory in ice box for further processing.

A part of whole milk and skimmed milk (obtained after centrifugation at $3000 \mathrm{rpm}$ for 20 minutes at $4^{0} \mathrm{C}$ ) were stored at $-20^{\circ} \mathrm{C}$ for analysis of NAGase activity. Blood samples $(\sim 10 \mathrm{ml})$ were drawn in sterile heparinised vacutainer from each cow by jugular vein puncture. Immediately after collection the tubes were transported to the laboratory in ice box for further processing. The plasma was separated out by centrifugation at $3000 \mathrm{rpm}$ for 15 minutes and stored at $-20^{\circ} \mathrm{C}$ in different aliquots, for analysis of NAGase activity. 


\section{Results and Discussion}

NAGase level was significantly higher $(p<0.05)$ in clinical mastitis infected Sahiwal cows as compared to the subclinical mastitis in both plasma (except summer) and milk samples. The levels were highest during summers $(38.18 \pm 5.99$ and $33.14 \pm 4.94$ $\mathrm{ng} / \mathrm{ml})$ followed by winter $(34.02 \pm 1.34$ and
$40.47 \pm 8.28 \mathrm{ng} / \mathrm{ml}$ ) and thermoneutral conditions $(26.44 \pm 1.61$ and $22.13 \pm 1.68$ $\mathrm{ng} / \mathrm{ml}$ ) respectively in the plasma of the both clinical and subclinical mastitis infected Sahiwal cows. Clinical mastitis cases had significantly higher $(\mathrm{P}<0.05)$ milk NAGase levels as compared to subclinical mastitis cases. However, these differences were not significant for different seasons.

Fig.1 Temperature Humidity Index during experimental period

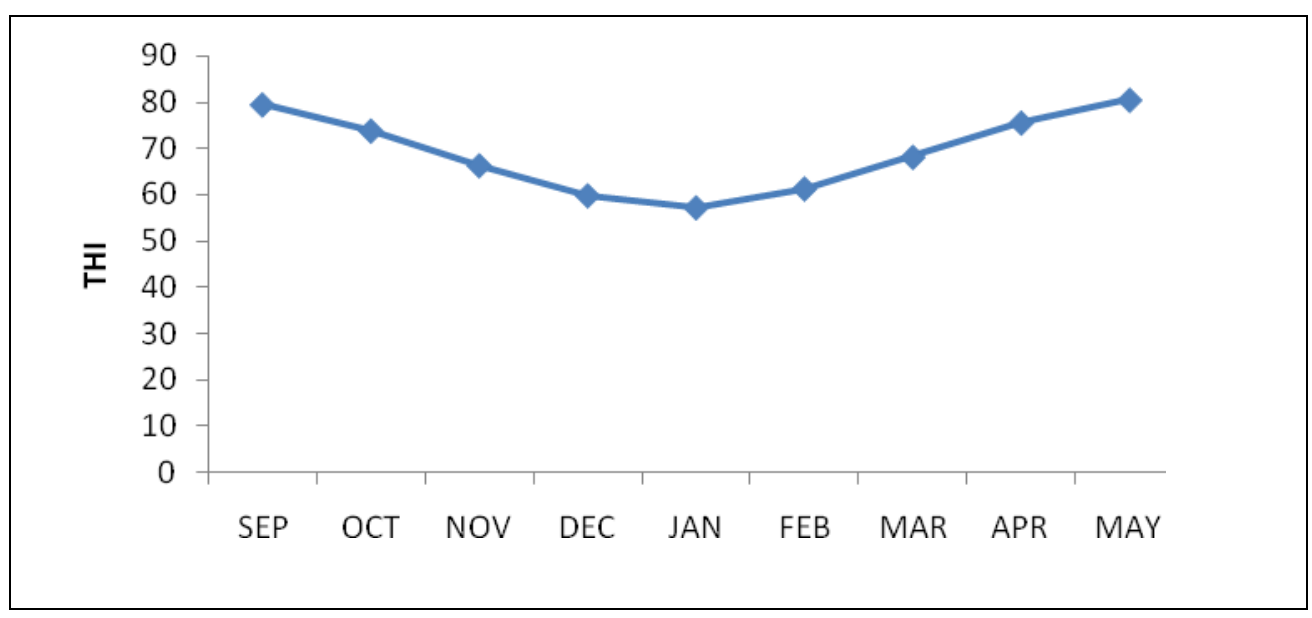

Fig.2 Variations in plasma N-acetyl -beta-D- glucosaminidase in Sahiwal cows suffering from clinical and subclinical mastitis in different seasons

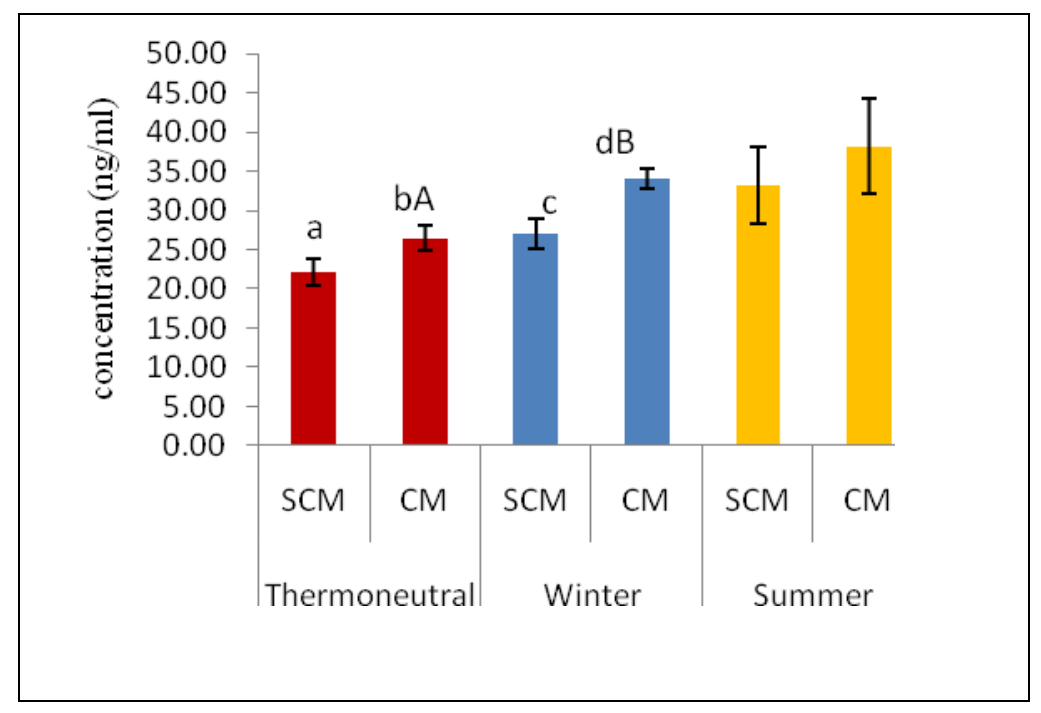


Fig.3 Variations in milk N-acetyl -beta-D- glucosaminidase in Sahiwal cows suffering from clinical and subclinical mastitis in different seasons

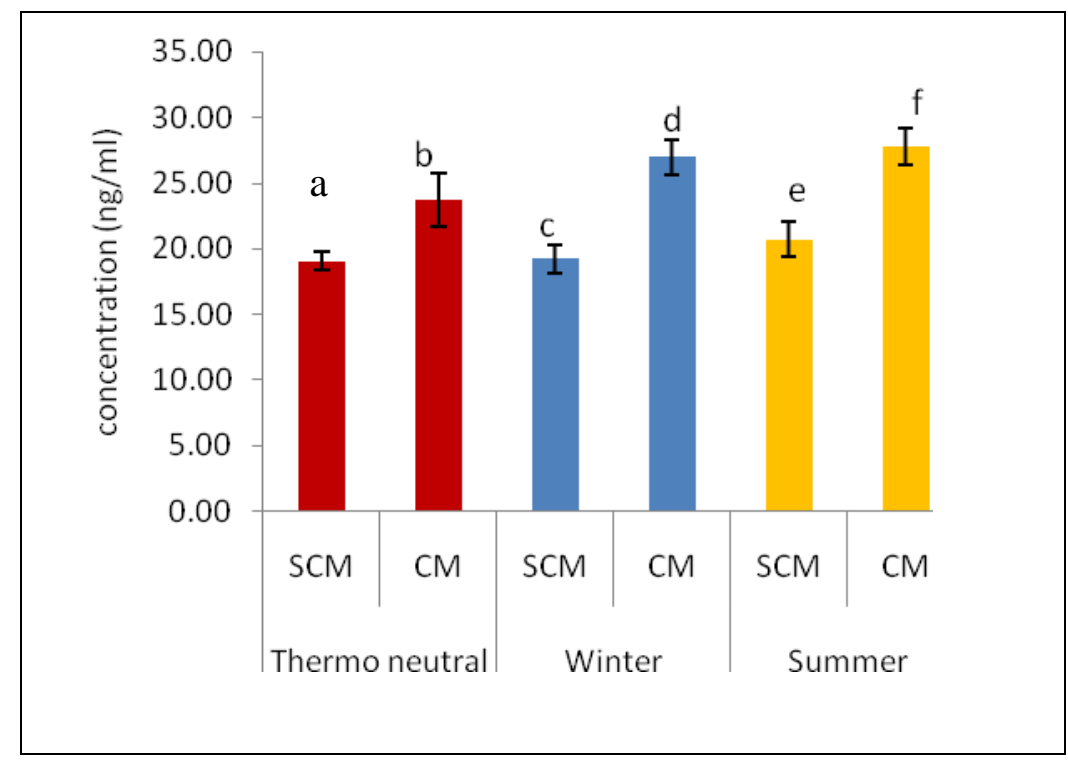

NAGase is an intracellular lysosomal enzyme that is released into milk from lysis of mammary tissue and to some degree by damaged epithelial cells of mammary tissue (Kitchen et al., 1978, 1980; Fox et al., 1988) reflecting destruction of udder tissue and also during lysis of inflammatory neutrophils (Kitchen et al., 1978; Kaartinen et al., 1988). Milk somatic cells contribute less than $15 \%$ of the total milk NAGase activity (Fox et al., 1988). To the best of our knowledge there are no comprehensive reports in blood and milk for evaluation of clinical or subclinical mastitis in different seasons in Indian context.

Hovinen et al., (2016) indicated that milk NAGase activity could be used to detect both subclinical and clinical mastitis with a high level of accuracy (0.85 and 0.99) compared with other studies (Urech et al., 1999; Bansal et al., 2005; Nielsen et al., 2005). However, compared with the findings of Chagunda et $a l .$, (2006a), the performance of milk NAGase activity in this study was better than milk Llactate dehydrogenase in their study, probably because of using quarter milk and not composite milk. Our data is in conformity to above references wherein we found significantly higher $(\mathrm{p}<0.05)$ levels of NAGase in clinical mastitis infected Sahiwal cows as compared to the subclinical mastitis in both plasma and milk samples. The levels were highest during summers followed by winter and thermoneutral conditions in the plasma of the both clinical and subclinical mastitis infected Sahiwal cows $(\mathrm{P}<0.05)$. The seasonal differences in the occurrence of $\mathrm{CM}$ were significant during winter and thermoneutral conditions. These variations could be accounted for differences in SCC during different seasons as suggested by Miller and Paape, (1988); Berning and Shook, (1992) who correlated its activity closely with SCC. Nagahata et al., (1987) studied relationship between the CMT results of milk and their NAGase and B-Gase activities. The CMT scores of each group appeared to be well correlated with the levels of NAGase and B-Gase activity ( $r=0.86$ for NAGase and $r=$ 0.92 for B-Gase). At CMT score 3, their activities increased remarkably and showed increments of 33-fold for NAGase and tenfold 
for B-Gase, in comparison with those of normal milk at CMT score of 5. Pyorala et al., (2011) reported Milk NAGase activity was significantly higher in the group with clinical mastitis than in the group with subclinical mastitis. Unlike milk SCC, a high NAGase activity was suggestive of likely destruction of epithelial cell in the udder, which might help to assess the prognosis for recovery from mastitis.

Due to epithelial origin of NAGase, this test could effectively be used to separate healthy quarters from those with subclinical (Urech et al., 1999; Bansal et al., 2005; Nielsen et al., 2005) or clinical mastitis (Chagunda et al., 2006; Larsen et al., 2010). Hovinen et al., (2016) suggested that this test performed very well in separating quarters infected with major pathogens from those with minor pathogens. Overall, milk from quarters with clinical mastitis had much higher NAGase activity than in milk from quarters with subclinical mastitis.

It is concluded thus milk NAGase activity was found to be the most potential candidate which could be considered for detection of subclinical mastitis during different seasons.

\section{References}

Bansal, B. K. Hamann, J., Grabowski, N. T., and Singh, K. B. (2005). Variation in the composition of selected milk fraction samples from healthy and mastitic quarters, and its significance for mastitis diagnosis. Journal of Dairy Research, 72(2), 144-152.

Berning, L. M., and Shook, G. E. (1992). Prediction of mastitis using milk somatic cell count, N-acetyl- $\beta$-Dglucosaminidase, and lactose. Journal of Dairy Science, 75(7), 1840-1848.

Boehmer, J. L., Bannerman, D. D., Shefcheck, K., and Ward, J. L. (2008).
Proteomic analysis of differentially expressed proteins in bovine milk during experimentally induced Escherichia coli mastitis. Journal of dairy science, 91(11), 4206-4218.

Chagunda, M. G., Larsen, T., Bjerring, M., and Ingvartsen, K. L. (2006). L-lactate dehydrogenase and N-acetyl- $\beta$-Dglucosaminidase activities in bovine milk as indicators of non-specific mastitis. Journal of Dairy Research, 73(4), 431-440.

Fox, L. K., Hancock, D. D., McDonald, J. S., and Gaskins, C. T. (1988). N-Acetyl- $\beta$ D-Glucosaminidase Activity in Whole Milk and Milk Fractions1. Journal of dairy science, 71(11), 2915-2922

Healy, P. J., Farrow, B. R., Nicholas, F. W., Hedberg, K., Ratcliffe, R. (1984). Canine fucosidosis: A biochemical and genetic investigation. Res Vet Sci., 36:354-359.

Hovinen, M., Simojoki, H., Pösö, R., Suolaniemi, J., Kalmus, P., Suojala, L., and Pyörälä, S. (2016). N-acetyl- $\beta-D-$ glucosaminidase activity in cow milk as an indicator of mastitis. Journal of Dairy Research, 83(2), 219-227.

Kaartinen, L., Kuosa, P. L., Veijalainen, K., and Sandholm, M. (1988). Compartmentalization of Milk $\mathrm{N}$ - acetyl- $\beta$ - D- glucosaminidase (NAGase). Zoonoses and Public Health, 35(1- 10), 408-414.

Kitchen, B. J. (1981). Bovine mastitis: milk compositional changes and related diagnostic tests. Journal of Dairy Research, 48(1), 167-188.

Kitchen, B. J., Kwee, W. S., Middleton, G., and Andrews, R. J. (1984). Relationship between the level of N-acetyl- $\beta$-Dglucosaminidase (NAGase) in bovine milk and the presence of mastitis pathogens. Journal of Dairy Research, 51(1), 11-16.

Kitchen, B. J., Middleton, G., and Salmon, M. 
(1978). Bovine milk N-acetyl- $\beta$-Dglucosaminidase and its significance in the detection of abnormal udder secretions. Journal of Dairy Research, 45(1), 15-20.

Larsen, T., Røntved, C. M., Ingvartsen, K. L., Vels, L., and Bjerring, M. (2010). Enzyme activity and acute phase proteins in milk utilized as indicators of acute clinical E. coli LPS-induced mastitis. Animal, 4(10), 1672-1679.

Mattila, T., Syväjärvi, J., and Sandholm, M. (1986). Milk Antitrypsin, NAGase, Plasmin and Bacterial Replication Rate in Whey Effects of Lactation Stage, Parity and Daily Milk Yield. Zoonoses and Public Health, 33(1- 10), 462-470.

Mellors, A. (1968). $\beta$-N-Acetylglucosaminase in bovine milk. Canadian journal of biochemistry, 46(5), 451-455.

Miller, R. H., and Paape, M. J. (1988). Effects of parity, bacteriological status, stage of lactation, and dry period on $\mathrm{N}$-acetyl- $\beta$ D-glucosaminidase activity of milk and dry secretion. Journal of Dairy Science, 71(9), 2508-2512.

Nagahata, H., Saito, S., and Noda, H. (1987). Changes in N-acetyl-BDglucosaminidase and B-glucuronidase activities in milk during bovine mastitis. Canadian Journal of Veterinary Research, 51(1), 126.

Nielsen, N. I., Larsen, T., Bjerring, M., and Ingvartsen, K. L. (2005). Quarter health, milking interval, and sampling time during milking affect the concentration of milk constituents. Journal of Dairy Science, 88(9), 3186-3200.

Pyörälä, S. (2003). Indicators of inflammation in the diagnosis of mastitis. Veterinary research, 34(5), 565-578.

Pyörälä, S., and Syväjärvi, J. (1987). Bovine acute mastitis: Part II. Effect of mastitis pathogen, initial inflammatory reaction and therapy on the outcome of the disease. Zoonoses and Public Health, 34(1- 10), 629-639.

Pyörälä, S., Hovinen, M., Simojoki, H., Fitzpatrick, J., Eckersall, P. D., \&Orro, T. (2011). Acute phase proteins in milk in naturally acquired bovine mastitis caused by different pathogens. Veterinary Record-English Edition, 168(20), 535.

Sordillo, L. M. (2005). Factors affecting mammary gland immunity and mastitis susceptibility. Livestock Science, 98(1), 89-99.

Ulberth, F., Foissy, H., Neumeister, E. (1984). ZumEinsatz der N-Acetyl-B-DGlucosaminidase Aktivitat in Milchals Mastitis Indicator. Wien Tieraerztl Monatschr 1984; 71: 273-279.

Urech, E., Puhan, Z., \&Schällibaum, M. (1999). Changes in milk protein fraction as affected by subclinical mastitis. Journal of Dairy Science, 82(11), 24022411.

Vicente, R. V. (2014). Economic losses from mastitis: intensive dairy farm case study from Valencia, Spain (Master's thesis).

Viguier, C., Arora, S., Gilmartin, N., Welbeck, K., and O'Kennedy, R. (2009). Mastitis detection: current trends and future perspectives. Trends in biotechnology, 27(8), 486-493.

\section{How to cite this article:}

Selva Rani, R., Sujata Pandita and Manju Ashutosh. 2020. Milk NAGase Activity as an Indicator of Subclinical and Clinical Mastitis in Sahiwal Cows. Int.J.Curr.Microbiol.App.Sci. 9(06): 4189-4194. doi: https://doi.org/10.20546/ijcmas.2020.906.490 